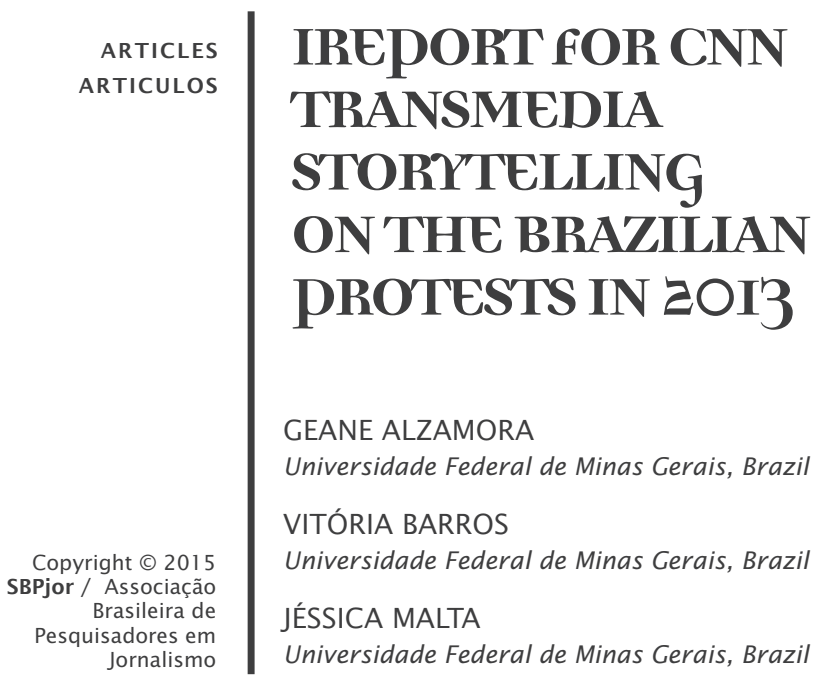

\begin{abstract}
This study discusses the limits and potentials of the concept of transmedia storytelling to describe citizen coverage of the 2013 protests in Brazil in the collaborative section iReport for CNN on CNN.com. The section is characteristically intermedia because it connects to online social networks and doubles as a monthly television program with the same name. But to what extent could it also be characterized as transmedia? Systematic observation of the citizen coverage between June and July 2013 revealed a restructuring of certain editorial spaces on the site aimed at user-proposed perspectives as well as communicational activity across online social networks; both important aspects for its transmedia characterization. Furthermore, the visible hierarchical differentiation of journalistic reporting puts the transmediatic potential of the collaborative experiment into perspective by reducing the importance of expanding the narrative horizontally despite the study showing regular social scheduling for journalistic coverage as evidence of the dynamics of transmedia.
\end{abstract}

Keywords: Transmedia Storytelling. Collaborative Journalism. Protests. iReport for CNN.

\title{
A NARRATIVA TRANSMIDIÁTICA DE IREPORT FOR CNN ACERCA DOS PROTESTOS BRASILEIROS DE 2013
}

RESUMO - O trabalho discute limites e potencialidades da noção de narrativa transmídia para descrever a cobertura cidadã dos protestos brasileiros de 2013 na seção colaborativa iReport for CNN do site CNN.com. A seção é tipicamente intermídia porque se conecta a redes sociais online e se desdobra em programa televisivo mensal de mesmo nome. Mas em que medida poderia também ser caracterizada como transmídia? Por meio da observação sistemática dessa cobertura cidadã entre junho e julho de 2013, verificou-se a reconfiguração de certos espaços editoriais no site visando a perspectiva proposta pelos usuários, assim como presença de atividade comunicacional em redes sociais online, aspectos importantes em sua caracterização transmidiática. Por outro lado, a diferenciação hierárquica do relato jornalístico observada relativiza o potencial 
transmidiático do experimento colaborativo porque reduz a relevância da expansão horizontalizada da narrativa, embora o estudo demonstre recorrente agendamento social da cobertura jornalística, o que remete à dinâmica transmídia.

Palavras-chave: Narrativa transmídia; jornalismo colaborativo; protestos; iReport for CNN.

\section{LA NARRATIVA TRANSMEDIA DE IREPORT FOR CNN SOBRE E LAS PROTESTAS EN BRASIL EN 2013}

RESUMEN - El artículo discute los límites y las potencialidades de la narrativa transmedia para describir la noción de cobertura ciudadana de las protestas brasileñas de 2013 en la sección colaborativa iReport del sitio web de CN. La sección es típicamente intermedia, ya que se conecta a las redes sociales en línea y se desarrolla en el programa de televisión mensual del mismo nombre. Pero ¿hasta qué punto también podría ser caracterizado como transmedia? A través de la observación sistemática de esta cobertura ciudadana entre junio y julio de 2013 , se produjo una reconfiguración de ciertos espacios editoriales en el sitio destinado a la perspectiva propuesta por los usuarios, así como la presencia de actividad de comunicación en las redes sociales en línea, aspectos importantes en su caracterización transmedia. Por otra parte, la diferenciación jerárquica del informe periódico observado relativiza el potencial transmedia del experimento de colaboración, ya que reduce la importancia de la expansión por horizontalidad de la narración, aunque el estudio muestra que el agendamiento social de la cobertura de noticias era recurrente, lo que se refiere a la dinámica transmedia.

Palabras clave: Narrativa transmedia. Periodismo de colaboración. Protestas. iReport for CNN.

\section{INTRODUCTION}

The collaborative program iReport for CNN, online since 2006 on CNN.com, differentiates itself from other programs by integrating television journalism broadcasting (which $\mathrm{CNN}$ is internationally known for) with the content sharing so characteristic of online social networks, constructing narratives that run between classic journalism and citizen reports. In 2011, iReport for CNN was restructured to operate as a social news network. The information on the site supports forms of peer validation combined with CNN editorial guidelines in an interactional dynamic to improve on citizen contributions in accordance with traditional journalism precepts. Based on these precepts, editors at CNN select contributions posted by citizen journalists, called iReporters, and include them in its broadcast programming, specifically the half-hour monthly programme iReport for CNN. The contributions are available in the OnCNN feature at CNN.com.

The citizen reports registered on IReport for CNN also expand across online social networks like Twitter, Facebook, Flicker, Tumblr and Instagram and are accessible in special formats for access on mobile devices such as tablets and smartphones. It is 
therefore a very rich communicational experience which brings about a few questions such as: what are the specifics behind overlapping mediations that characterize and qualify the reports circulating across online social networks and television? In what way and to what extent do these mediations and interactional processes configure transmedia storytelling? And in a broader sense, what are the consequences that this type of communication can bring to the concept of contemporary journalism?

These questions conducted our daily observation of citizen coverage of the Brazilian protests posted on iReport for CNN that dominated the country between June and July 2013. All the iReport for CNN posts on this issue were collected manually and the communication in forms of access, comments and shares were observed on a daily basis. The Assignments and OnCNN categories were systematically monitored to assess how the intersection of citizen and journalistic mediation affects communication activities. The Assignments category features contributions on iReport for $C N N$ and the OnCNN category compiles the contributions that were broadcast on its program. Communicational activity generated on the posts was examined according to: its importance to citizens; $b$ ) the criteria for newsworthy journalism; c) and its transmediatic potential.

\section{IREPORT FOR CNN IN INTERMEDIA CONNECTIONS}

Founded in 1980, the Cable News Network (CNN) has developed a segmented model of telejournalism that has spread around the world in several similar editorial initiatives, becoming a symbolic reference for contemporary telejournalism. The CNN editorial project is based on traditional journalistic mediation, while the experiment examined in this study merges aspects of journalistic mediation with citizen mediation by means of technological mediation which highlights the interactive possibilities that iReport for CNN has for online social networking and television.

Mediation processes take into account a "power to discriminate, to make distinctions, a symbolic place, and a founder of knowledge" (SODRÉ, 2002, p. 21). Journalistic mediation configures a specific symbolism because it selects, hierarchizes and distributes information based on journalistic knowledge. However, journalistic mediation has been put under increasing stress by social media, 
underlining the plurality of perspectives that shape contemporary flows of information and establish new zones of power and knowledge in society (ALZAMORA, 2011 ).

The hybrid forms of mediation in iReport for CNN constitute a kind of "mediation spiral", an expression coined by Gómez (2006) to describe the transversal scene of media segmentation. "I consider mediations as structuring processes that originate from multiple sources and focus on processes of communication and forming communicative interactions between social actors (GÓMEZ, 2006 , p. 88). The amalgamation of mediations in iReport for CNN translates across varying degrees of social participation. According to Hellmueller and Li (2014), there are at least three positions of social participation on iReport for CNN: commentators, eyewitnesses and co-workers. Commentators only share personal opinions about what was published; eyewitnesses submit textual, visual and audio visual records of events related or unrelated to those reported on by the editors at iReport for CNN; and co-authors are citizens working together with journalists from CNN to cover specific events.

These roles have emerged gradually and today co-exist in a collaborative experiment which, according to Hellmueller and Li (2014), points toward the weaving together of functions in an increasingly complex web of proposing, evaluating, editing and selecting reports for IReport for CNN, although the editorial control is restricted to journalists. Hellmueller and $\mathrm{Li}$ (2014) consider that the different modalities of participation in iReport end up reducing the differences of opinion that professionals and amateurs have over how the news should be produced, and therefore establishing a form of participatory journalism founded on integrated work between the audience and journalists. According to these authors, this is seen in the concept of participatory journalism described by Axel Bruns (2009) in which journalists and citizens share in the processes of selecting and editing information.

Bruns (2009) coined the term gatewatching to describe the process of contextualisation and interpretation of information in participatory journalism; the gatewatcher being the one who guides the paths between the various voices spread across the internet. As Bruns (2009) states, if the term gatekeeping (used to describe the processes of selection and prioritisation of information in the mass media) is a metaphor for a doorman, then the term gatewatching is a metaphor for a librarian. Bruns (2009) describes that in participatory 
journalism the journalist is not the doorman of information, they are the librarians, similar to that of a prosumer.

In the hybrid and plural context of iReport for CNN, it is possible to recognize aspects of journalistic mediation in various degrees of interaction between journalists and participants. The categories Open Story, Blog, Assignments and On CNN are examples of this. Open Story configures_integrated efforts of iReporters and CNN journalists when covering a particular event. For the blog, members of Team iReports comment on contributions; an important interaction for improving the posts. Assignments are ideas for issues to be covered which are suggested by Team iReports, whose contributions often result in stories aired on CNN television programmes, particularly on the monthly program iReport for CNN. On CNN registers the stories that citizens post on IReport for CNN that had previously been checked by Team iReports and then later broadcast on television. This study is particularly interested in the Assignment and OnCNN features which screened the citizen coverage registered on iReport for CNN of the Brazilian protests in 2013.

The half-hour television program iReport for CNN is broadcast on the third week of each month on CNN International. The host, editor and journalist Errol Barnertt is responsible for all media facets of the program. The show differentiates itself by modifying the broadcast and sharing times; On CNN presents an extended duration of the iReport for CNN program. It is a mix between linear temporality of journalistic editions and varied temporality of databases (WEISSBERG, 2004). The collaborative experiment differs mainly by introducing a differentiated logic in telejournalism than CNN has; it authenticates citizen participation for the production of news and measures the social importance of the posted contributions. It is neither an online social network nor a television journal, but a hybrid form of mediation resulting in a hybrid form of language.

According to Barbero (2009), hybrid forms of communication arise from the dynamics of contamination that destabilize the discourse of each form, and reconfigure the media and its discourses. Thus, iReport for CNN destabilizes references of telejournalism language to the same extent that posts on online social networks mediated by editors at iReport for CNN distance themselves from the typical colloquial tone of these environments. It is therefore a hybrid form of communication and, as such, cannot be classified into any of the other previous classifications. 
The "hybridization" of iReport for CNN is a reference to the nuances of intermedia which characterize the movement of content across varied media environments, in order to emphasize language overlaps and the exchange of meaning between one form and another (HIGGINS, 2012). In a digital context, in which media accessibility is heightened (WEINZ, 2008), the dynamics of intermedia become even more sophisticated, resulting in hybrid forms of communication such as iReport for CNN.

What draws attention to iReport for $C N N$ is not just its intense communicational activity resulting from a sophisticated experiment of collaborative and intermedia journalism, but also the reconfiguration of the characteristics of telejournalism, visible in the amalgamation of formats and the apparent revision of certain newsworthy criteria, in particular those related to the construction of the news. Newsworthy criteria are sets of values shared by journalists that guide the selection and construction processes. According to Traquina (2005), image quality is an observable criteria in constructing news, but iReport for CNN is increasingly interested in pictures that reflect reality and are believable, that is to say, their ability to record reality even though not having been produced according to journalistic standards (ALZAMORA, 2011). The inconsistency of amateur images taken by eyewitnesses for iReport for CNN is no longer a barrier in journalism because it shows the degree to which eyewitness accounts are valued on online social networks. Therefore, in this experiment journalistic mediation ends up incorporating something that had never even been considered before. This process was observed on numerous occasions on CNN's coverage of the Brazilian protests of 2013 - many of which were based on citizen reports featured on iReport for $C N N^{1}$.

\section{THE BRAZILIAN PROTESTS OF 2013 ON IREPORT FOR CNN}

In June of 2013, while protests were spreading against the Confederations Cup being held in the country, iReporters in Brazil came up with the idea to write about tourist attractions in the country that would be hosting huge sporting events such as the Confederations Cup (2013), World Cup (2014) and the Olympic Games (2016), and include them in the feature Assignment. Created on May 30, 2013 the Assignment "What do you love most about Brazil"2 reached a 
total of 62 posts before it expired on July 1, 2013. From June 14, 2013 onwards, as a collective gesture of social appreciation for this editorial space, the Assignment received 10 posts about the protests that had broken out in São Paulo the previous day and eventually spread throughout the country.

The editorial redirection of Assignment, which these posts helped create, led to the release of the Assignment "Protests break out in Brazil"3 on June 18, 2013. This fact highlights the strength of citizen mediation on iReport for CNN as it interfered with the traditional scheduling processes firmly established in the hypothesis that it is journalism that provides the issues and shapes our daily conversation. McCombs (2004), one of the founders of the theory of Agenda Setting in the 1970s, highlights the relevance of intermedia agenda-setting in contemporary agendas. According to the author, the internet allows for small groups to influence other small groups, and even the mass media depending on the scope of the network. The social appropriation of the Assignment on tourism in Brazil followed by the immediate opening of the specific Assignment about the Brazilian protests exemplifies the process of intermedia agendasetting described by McCombs (2004).

The Assignment on the Brazilian protests was a feature on the website's homepage between June 18 and 25, 2013. It accounted for 325 contributions between June 18 and July 1, 2013. During this period, the Assignment stored 146 photos, 51 pictures with comments, 83 videos, 44 text reports and only one audio piece. This data shows the prevalence of the use of images in contemporary citizen participation, and consequently the importance of mobile communication devices for the production and circulation of information across intermedia networks ${ }^{4}$. The images recorded on Assignment are panoramic and show details of people in the streets, with dates and locations. It has an almost impersonal feel to it even though the eyewitness contributions are obvious. Hellmueller and Li (2014) consider an eyewitness account as a kind of participation that humanizes and diversifies the stories. Posts that critiqued the demonstrations were not observed. The titles make it possible to identify the iReports coming from various places in Brazil which shows a geographically dispersed and collective effort to register the magnitude of the protests in the country ${ }^{5}$.

The communicational activity revolving around the Assignment also made its way to online social networks linked to the 
site. For example, the iReport for CNN Facebook page had two news reports about the protests in 2013 posted by Team iReports. The first one, on June 17, explained the context and the reasons why people took to the streets. The second one, on June 18, announced and invited people to submit their reports to Assignment. Written almost exclusively in English, the comments posted on Facebook represented a collective effort to explain to the international community of iReport for CNN why Brazilians were marching on the streets in protest. 16 of the 35 registered comments clearly spoke about this.

The Assignment "What's really behind the Brazilian riots ${ }^{6}$ ?" was the contribution that generated the most communicational activity with a total of 341,144 views, 484 comments and 161 shares?. This was the first of 26 posts on the issue to appear on OnCNN. It contains photographs showing the people in the streets of São Paulo carrying signs written in Portuguese and English, which facilitates broadcasting for CNN International. Selecting this contribution for television viewing is a reflection of newsworthy criteria; standards such as importance, topicality, uniqueness and availability (TRAQUINA, 2005) which were probably guiding the registration process, albeit intuitively, at iReporter ${ }^{8}$. The communicational activity generated around this post suggests that social engagement - an important aspect of transmedia storytelling - tends to be a factor when selecting what citizen participation will be shown on television.

\section{TRANSMEDIA DYNAMICS FOR IREPORT FOR CNN}

A transmedia story unfolds across multiple media channels so that each new text is contributing differently to the whole (JENKINS, 2008). Transmedia storytelling expands from one medium to another through the profusion of languages and the exchange of senses, which in turn makes it intermedia. It is not, however, an adaptation or an intersemiotic translation because transmedia storytelling presents an autonomy of meanings in each media channel it is told on. According to Jenkins (2008), the expansion of transmedia storytelling occurs both vertically, in actions institutionalized by media corporations, and horizontally, in collective citizen participation.

According to Scolari (2013), transmedia journalism must deal with at least two aspects: a) the story should be told across different media in an autonomous yet complementary way; b) the 
prosumers should participate in the production of the narrative. These aspects tell us that the reports posted by citizens ${ }^{9}$ on iReport for CNN configure transmedia narratives when they spread across television and online social networks in an intermedia expansion of user and journalist actions.

One must recognize, however, that regular adaptations to citizen reports on CNN impose a limit on transmedia expansion. According to Stam (2006), the adaptation process involves two texts which presumably communicate the same narrative. This process, which is not characterized by transmedia narrative because it does not expand content, shows the differentiated value of journalistic mediation on CNN even when it is based on citizen mediation from the contributions on iReport for CNN. It was observed that citizen mediation posted on iReport for CNN was important to journalistic mediation at CNN when referring to newsworthy criteria and distinctive aspects of journalism, such as the logic of speed and a preference for live events (MARCONDES FILHO, 2000).

However, transmedia journalism operates on expansion, exploration and diverse points of view (SCOLARI, 2013); aspects that could eventually distance themselves from the canonical model of telejournalism as a result of the varied criteria of importance configured by citizen mediation. According to Renó and Ruiz (2014), the fundamental characteristics of transmedia journalism are participation, content feedback, circulation of content on social networks, mobility and Intertextuality between content. According to the authors, these aspects spread throughout contemporary participatory journalism which makes it suitable for transmediatic experiences. In light of that, citizen coverage of the protests in 2013 posted on iReport for CNN is an example of transmedia journalism. Citizen participation is evident in the production and editing of posted information as well as in content feedback as noted in the editorial redefinition of the Assignment about Brazil. The content available on iReport for CNN was produced in the intersection between journalistic and citizen mediation, it circulated across online social networks, was captured on the streets by mobile communication devices and configured forms of intertextuality across television and the internet by being broadcast on CNN television.

The problem occurs when transmedia narratives for iReport for CNN are seen on a broader context on CNN. The Assignment on the Brazilian protests of 2013 contributed, in part, to elaborating on a series of reports from $\mathrm{CNN}$ on the event. All these reports mentioning 
the Assignment ${ }^{10}$ were registered on the CNN website, yet they were placed at the bottom of the page, a clear example of how citizen contributions are kept to the peripherals of journalistic reporting. The reports from CNN journalists on the Brazilian protests of 2013 were clear examples of intermedia, not only because they ran across television, CNN.com and CNN online social network pages, but also because they continually used images produced by journalists at TV Bandeirantes in Brazil; a television station which has a partnership agreement ${ }^{11}$ with CNN. However, these news stories did not have the same relationship of symmetry as the citizen contributions posted on iReport for CNN, which highlights the differentiated value of journalistic mediation in this coverage.

"What's really behind the Brazilian riots ${ }^{12}$ ?" is the mostviewed contribution on Assignment. It reveals how the singular transmedia dynamics of IReport for CNN keep citizen participation to the sidelines in broadcasting, yet at the same time incorporate the journalistic report in citizen participation in order to legitimize it for iReport for CNN. The post, signed by publishing firm Jareen, stated that iReporter phillipviana registered photos of the protests taken with his iPhone in downtown São Paulo on June 13, 2013 and, according to iReporter, the demonstrations were initially related to the fare increase to public transportation in São Paulo. There is a link in the editor's note to journalistic material produced by $\mathrm{CNN}^{13}$ on the same event, therefore verifying the citizen report.

This link shows the dynamics of hierarchical transmedia at iReporterfor CNN. Even though it presents aspects such as participation, content feedback, circulation of content in social networks, mobility and intertextuality across content (RENÓ; RUIZ, 2014), it maintains the superiority of journalistic mediation over citizen mediation. In our view, this is putting a limit on the whole constitutional dynamics of journalistic transmedia as it is characterized by movement and transformation which are fundamentally participatory (RENÓ; RUIZ, 2014). In order to take full advantage of the dynamics of transmedia, journalistic mediation should be integrated, and not autonomous, so as to add to the social collective movement (ARCE; ALZAMORA; SALGADO, 2014); which is the case for posting on iReport for CNN, but not so for CNN reports on the same topic. So, if you look at this through the eye of collaborative journalism, iReport for CNN is an example of transmedia journalism, but not if it is biased toward telejournalism, even though in this case one is subject to the other. 
Branding, the marketing strategy symbolic of journalistic mediation, is visibly imprinted on iReport for CNN. For example, descriptions on editors posts, the symbol in the upper left corner of the image taken by iReport and in the notice stating that all information was checked by Team iReport. The inscription "not verified by CNN" announces the opposite; that the citizen participation has not been checked by CNN. What is more interesting, however, is the fact that not being checked by CNN does not make the citizen participation less relevant to the network. For example, the "Protests in João Pessoa ${ }^{14 "}$ video posted on June 20, 2013 is one of the most-viewed reports on iReport for CNN (a total of 7,549 hits) despite not having been checked by Team iReport. Interestingly, the set of photographs titled "Why are you protesting ${ }^{15}$ ?" had been checked by the editors and had a total of only 1,197 hits.

Another interesting bit of data to note is the number of times these two contributions were shared. The aforementioned unchecked CNN video had only 4 shares, while the set of photographs checked by CNN had 126 shares. What does this discrepancy reveal? On one hand, you have to consider the weight of journalistic mediation on the decision to share, something that seems to corroborate the belief that knowledge produced by journalistic mediation is differentiated. On the other hand, the decision to view_citizen contribution seems to legitimize the network's criteria of what is important for posting contributions on iReport for CNN; to the detriment of traditional journalistic mediation. The overlapping social and journalistic mediations in iReport for CNN are evidence of transmedia configuration yet, it is sharing that encourages the intermedia expansion of journalistic mediation.

\section{CONCLUSIONS}

The results of this study suggest that the practice of contemporary journalism, when based on digital media connections, experiences profound transformations. These transformations are primarily changes that emerge from increasingly intense intersections between broadcasting and sharing, but they also emerge out of a type of varied, tempered eyewitness account in contemporary journalistic practices. 
We also see that journalistic practice in interconnecting digital environments does not only rely on the presupposed sociocultural conditions of interactions across online social networks; it also ends up interfering with how information is produced and circulated in these environments. On the other hand, the analysis demonstrates that journalistic mediation is not weakening in the face of these challenges, it seems to be strengthening. This illustrates the fact that, for the most part, the communicational activity on iReport for CNN is guided by the suggested topics on Assignments as well as by the highlights on the homepage and the program's clear journalistic mediation. However, we must consider the actual users' criteria of importance used in certain Assignments to publish their eyewitness accounts on issues that appear urgent due to their socio-cultural contexts. This is illustrated well in the protests of 2013 because CNN itself legitimized the criteria of user importance and reshaped their Assignments when socially applicable.

In conclusion, if the socio-communicational dynamics of online social networks interfere in the production and circulation of journalistic information, then the thematic framework will be defined in large part by journalistic mediation agendas. This does not, however, eliminate the criteria of user importance, particularly when this same criteria mirrors the newsworthy criteria as evidenced in the protests of 2013 on iReport for CNN.

This study helps to refine our understanding of the range of journalistic mediation in the contemporary world and the ways it contaminates the dynamics of intermedia communication, especially in the context of citizen participation. In particular, this study helps put the horizontal transmedia journalism into perspective through analysis that accentuates the hierarchical separation that exists between journalistic and citizen reporting. However, in the context of collaborative journalism, it marks the important trend of social agenda setting in transmedia storytelling, as noted in the case of citizen coverage of the protests in 2013 .

*This paper was translated by Lee Sharp 


\section{BIBLIOGRAPHY}

ALZAMORA, Geane. Entre a TV e a internet: mediações sobrepostas em IReport for CNN. In: SOSTER, Demétrio; LIMA JÚNIOR, Walter Teixeira. Jornalismo digital - audiovisual, convergência e colaboração. Santa Cruz do Sul: Edunisc, 2011 (p. 84 - 104).

ALZAMORA, Geane; TÁRCIA, Lorena. Convergência e transmídia: galáxias semânticas e narrativas emergentes em Jornalismo. Brazilian Journalism Research (impresso), v. 8, p. 22-34, 2012.

ARCE, Tacyana; ALZAMORA, Geane; SALGADO, Tiago. Mediar, verbo defectivo - contribuições da Teoria Ator-Rede para a conjugação da mediação jornalística. Revista Contemporânea - Comunicação e Cultura - v.12 - n.03 - Sep.-Dec. 2014 - p. 495-511.

BARBERO, Jesus. As formas mestiças da mídia. Revista Fapesp online. Edição impressa 163, Setembro, 2009. Available at: http://revistapesquisa. fapesp.br/?art=3933\&bd=1\&pg=1. Accessed on: April 24/2010.

BRUNS, Axel. Gatewatching - collaborative online News produtction. New York: Peter Lang, 2009.

GÓMEZ, Guillermo O. Comunicação social e mudanças tecnológicas: mudanças e opacidades da comunicação no novo século. In: MORAES, Dênis (org). Sociedade midiatizada. Rio de Janeiro: Mauad, 2006 p.81-98.

HELLMUELLER, Lea; LI, You. Contest over content - a longitudinal study of the CNN iReport effect on the journalistic field. In: Journalism practice. Routledge, Taylor \& Francis, 2014, vol. 8 (5), 2014. p. 1-17.

HIGGINS, Dick. Intermídia. In: DINIZ, Thaïs F. N.; VIEIRA, André S. (Orgs.). Intermedialidade e estudos interartes: desafios da arte contemporânea. Belo Horizonte: Rona Editora, FALE/UFMG, 2012. p. 41-50.

JENKINS, Henry. Cultura da convergência Trad.: Susana Alexandria. São Paulo: Editora Aleph, 2008.

MARCONDES FILHO, Ciro. A saga dos cães perdidos. São Paulo: Hacker Editores, 2000.

MCCOMBS, Maxwell. Setting the agenda - the mass media and public opinion. Cambridge: Blackwell Publishing Inc., 2004.

MOTTA, Luís Gonzaga. Jornalismo e configuração narrativa da história do presente. Revista Contracampo, n. 12, 2005 - p 23-49. 
RENÓ, Dênis; RUIZ, Sandra. Reflexiones sobre periodismo ciudadano y narrativa transmedia. In: CAMPALANS, Carolina; RENÓ, Dênis; COSCIOLA, Vicente (orgs). Narrativas transmedia - entre teorias y prácticas. Rosário: Universidad del Rosario, 2014.

SCOLARI, Carlos. Narrativa Transmedia: cuando todos los medios contam. Barcelona: Deusto, 2013.

SODRÉ, Muniz. Antropológica do espelho - uma teoria da comunicação linear e em rede. Rio de Janeiro: Vozes, 2002.

STAM, Robert. Teoria e prática da adaptação - da fidelidade à intertextualidade. Ilha do Desterro - Revista de língua inglesa, literatura inglesa e estudos culturais. Universidade Federal de Santa Catarina, vol.5, 2006 p. 19 - 53. Available at: https://periodicos. ufsc.br/index.php/desterro/issue/view/653. Accessed on: Apr. $30 / 2015$.

TRAQUINA, Nelson. Teorias do Jornalismo - A tribo jornalística - uma comunidade interpretativa transnacional. Florianópolis : Insular. Volume II, 2005.

WEISSBERG, Jean-Louis. Paradoxos da teleinformática. In: PARENTE, André (Org.). Tramas da rede. Porto Alegre: Sulina, 2004, p. 113141.

WENZ, Karen. As formas intermidiáticas em textos digitais. In: SANTAELLA, Lúcia; NÖTH, Winfried (orgs). Palavra e imagem nas mídias - um estudo intercultural. Belém: Editora Universitária UFPA, 2008. p. 251-269.

\section{NOTES}

1 See, as an example, video shot by iReporter JacynaMarie on the streets of Rio de Janeiro, shown on OnCNN, despite her amateur technique. http://ireport.cnn.com/docs/DOC-992807. Accessed on: Apr.30/2015

2 http://ireport.cnn.com/topics/979601. Accessed on: Feb.20/2015.

3 http://ireport.cnn.com/topics/990706. Accessed on: Feb.20/2015

4 The CNN application for Google Glass, for example, not only allows you to receive news but also to send photographs and videos to IReport for CNN. http://www.techtimes.com/ 
articles/6825/20140511/google-glass-users-can-use-wearable-for-cnn-ireport-just-dont-get-mugged.htm. Accessed on: Apr.29/2015

5 The titles highlight the Brazilian cities of São Paulo, Vitória, Brasília, Rio de Janeiro, João Pessoa, Belo Horizonte, Florianópolis, Campo Grande, Goiânia, Belém, Vitória, Diadema, Manaus, Cotia, Juiz de Fora, Campinas, Sorocaba, Mauá, São Vicente, Vitória da Conquista, Joinville and Ribeirão Preto.

6 http://ireport.cnn.com/docs/DOC-988431. Accessed on: Apr. 30/2015.

7 http://ireport.cnn.com/docs/DOC-988431. Accessed on: Apr. $30 / 2015$.

8 iReport signs for the post under the codename phillipviana.

9 We make the distinction of narrative reports based on Motta (2005), who describes the report as a description of facts that are situated in time and space, while narratives are more elaborated and suggest the development of a temporal action which stimulates the imagination.

10 See, as an example, http://www.cnn.com/2013/06/28/world/americas/brazil-protests-favelas/. Accessed on: Feb.22/2015.

11 http://edition.cnn.com/videos/world/2013/06/19/pkg-darlingtonbrazil-protests.cnn. Accessed on: Apr.30/2015.

12 http://ireport.cnn.com/docs/DOC-988431. Accessed on: Apr. 30/2015.

13 http://edition.cnn.com/2013/06/14/world/americas/brazil-fareprotests. Accessed on: Apr. 30/2015.

14 http://ireport.cnn.com/docs/DOC-992496. Accessed on: Feb. $26 / 2015$.

15 http://ireport.cnn.com/docs/DOC-992723. Accessed on: Feb. 26/2015. 
Geane Carvalho Alzamora is productivity scholarship (CNPq) and Professor in the Social Communication Department at the Federal University of Minas Gerais, Brazil. She holds a PhD and MA in Communication and Semiotics from Pontifical Catholic University of São Paulo, Brazil; Dra. Alzamora's research related to the topic of this paper is supported by Capes, CNPq and Fapemig. E-mail: geanealzamora@ufmg.br

Vitória Barros is bachelor's degree in Social Communication and obtained a scholarship in research related to this study.

Jéssica Malta is bachelor's degree in Social Communication and obtained a scholarship in research related to this study. 